\title{
LIX. Description of a simple method of magnetizing steel bars
}

\section{P. Elias}

To cite this article: P. Elias (1844) LIX. Description of a simple method of magnetizing steel bars, Philosophical Magazine Series 3, 25:167, 348-350, DOI: $10.1080 / 14786444408645010$

To link to this article: http://dx.doi.org/10.1080/14786444408645010

Published online: 30 Apr 2009.

Submit your article to this journal ¿

Џll Article views: 2

Q View related articles $\sqsubset$ 


\section{M. Elias on a simple Method of Magnetizing Steel Bars.}

after the able experiments and inferences of Dr. Faraday and Mr. Armstrong, I should attribute the electricity to the friction of the water against the sides of the boiler, caused by rapid currents of steam passing from the bottom, aided by immense pressure and heat. If it were the steam carrying water, surely the greatest electrical force should be at the exit, and not at the sides; the steam may be a carrier and give shock. To show the conducting power of steam, attach a pith-ball by a silk thread and wax to an excited glass tube. On bringing this near a lighted candle the electricity is dissipated. The celebrated philosopher, $M$. Arago, states that this is occasioned by the conical blaze, whereas it arises from the va-

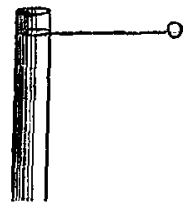
pour of the candle.

In my next communication to your valuable Journal I shall make known some perfectly new, and I hope interesting, experiments on the pyro-electricity of the glass cover of the binacle compass produced by the solar rays, giving a new view of that deflection of the needle which was attributed to local attraction. Humanity makes this a subject of great interest, and therefore $I$ shall give the experiments much attention.

JIX. Description of a Simple Method of Magnetizing Steel Bars. By P. Eluas of Haarlem*.

$A \mathrm{~T}$ the present day, when the possession of powerful steel A magnets must be desirable to experimentalists, it will perhaps not be without interest to many to become acquainted with the method by which the smallest needle as well as the heaviest steel bar can be instantly magnetized to saturation with the greatest facility.

'The method hitherto employed is that of the double passing, discovered by Knight and improved by Duhamel and Mitchell. Several persons have proposed the employment of electromagnets for this purpose, others suspending the steel bar to be magnetized at a red heat to the pole of an electro-magnet, and allowing it to cool in that position. The first method is inconvenient, as it is not possible to move electro-magnets about so freely as steel magnets; the latter, as every one knows, is without effect; consequently the old method has been retained. This however has the inconvenience, that in the first place it is necessary to be well acquainted with the manipulation of magnetizing; and secondly, that you must already possess that

* From Poggendorff's Annalen, vol. lxii. p. 249 ; conmunicated by W. Francis, Ph.D. 
which is to be made, viz. highly powerful magnets, which is rarely the case.

With my method I require nothing more than what every experimentalist possesses, and may be had everywhere, a powerful voltaic pair and some copper wire. From twenty-two to twenty-five feet of well-isolated copper wire are wound round to form a hollow, very short, but very thick cylinder (see woodcut). A strong current is passed through the wire,

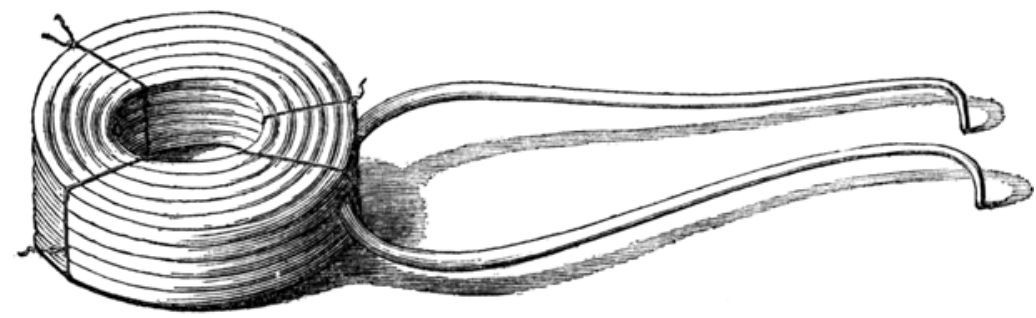

and the steel bar to be magnetized is placed in the cylinder, in which it is moved up and down to the very ends. When the central portion of the steel bar again occupies the cylinder, the circuit is opened, and the bar, which is now perfectly magnetized, withdrawn. When the bar is curved in the form of a horse-shoe, it is well to close it with its keeper during the magnetizing, and when a straight one, to provide it at top and bottom with a piece of soft iron. The wire which I employ is $\frac{1}{8}$ th of an inch in thickness. The thickness of the wire is not at all indifferent; the same effect it is true may be produced with a thinner one, but then it requires a battery of greater intensity. 'The voltaic apparatus which I make use of is a single platinum and zinc pair arranged on Grove's principle; it has $\frac{1}{3}$ rd square foot active platinum surface; the resistance which the current meets with in this battery is equal to that of a clean copper wire, 1 millimetre in diameter and $\frac{2}{3}$ rds of a metre in length $*$. The experiments however succeed perfectly well, even when the battery presents a twice or three times greater resistance. My hollow cylinder is 1 inch high, the bore is nearly $1 \frac{1}{2}$ inch in diameter, and its sides likewise $1 \frac{1}{2}$ inch thick.

To test the efficiency of iny magnetizing cylinder, a friend

* Since in Grove's battery the smallness of the resistence depends not merely on the size of the metallic surface, but likewise considerably on the goodness of the purous earthen cell, which cannot be determined, I have conceived it to be possible to indicate the power of the battery independent of the resistance only in this manner. 


\section{$350 \mathrm{Mr}$. Stagg on the prevention of Explosions in Collieries.}

of mine had a steel horse-shoe made, weighing thirty-four pounds, of one piece. It was magnetized to saturation by one single passage through a cylinder constructed purposely for this experiment; and a second magnet, after having been placed reversed in the cylinder, proved sufficient to change the poles without having lost its suspending power. Besides the facility and rapidity of this method, it has moreover the advantage, that a bar magnetized in this manner cannot possibly have intermediate poles; and if it previously had possessed any they disappear instantly in the magnetizing cylinder.

This mode is nothing more than the double passing of $\mathrm{Du}$ hamel or Mitchell, only by means of galvanism, and far more powerful, easy and certain. As in the double passing the opposite poles of the magnet employed must be kept close together, so as to exert successively their greatest action upon each small part of the bar to be magnetized, in like manner I make my cylinder quite short, that each portion of the bar may experience the entire force of the voltaic element.

My friend Dr. Munnich publicly repeated my experiments with the magnetizing cylinder at a meeting of the Utrecht Society of Naturalists; and the Faculty of the Physical Sciences which was present was convinced of the efficiency of the method. On this occasion he increased considerably the intensity of some very powerful bars belonging to the collection, and which had been magnetized by Knight himself, reversed their poles by a single passage, \&c.

Haarlem, March 7, 1844.

LX. Remarks relative to the Prevention of Explosions in Collieries. By J. D. STAGG, Esq.

To the Editors of the Philosophical Magazine and Journal. Gentlemen,

TTHE recent and very lamentable accident at Haswell Col1 liery (near Durham), whereby no less than ninety-five of our fellow-creatures were hurried into eternity, must occasion but one universal feeling of sorrow that such awful catastrophes cannot yet be prevented.

When we further consider the consequent misery of the surviving relatives, and the prospect that we are not in possession of any means of effectually guarding against the recurrence of such a fearful loss of human life, it shonld stimulate us to increased care in the working of collieries, and to endeavours to prevent the possibility of such events.

I am not practically acquainted with the winning of coal, but I beg to bring before the attention of better informed par- 